TURIZAM

Volume 19, Issue 3 98-110 (2015)

\title{
Attitudes of Local Population of Tourism Impacts on Destination Sustainability - Case of Croatia
}

Izidora Marković, Zoran Klarić*

Received: November 2014 | Accepted: August 2015

\begin{abstract}
Space as a resource is intensively used both by the tourism and the local community. Therefore the state of the tourism development must be measured trough time, along with attitudes of local population, to determine the impacts and the pressure that can continues tourism development cause. In the 1990s, tourism become the motor of the development of Croatia, which has resulted in continues increase of the number of tourist beds. On the other hand population of the Croatia is experiencing the demographic extinction. To explain pressures of the tourism development on the decreasing community, tourism function index was used in comparison with the research of the attitudes of local population considering tourism impacts. The main objective of this paper is to determine the correlation between the increase in the number of tourists and changes in the life of local population, which arises from the tourism activities in destinations, as well as from the ratio of the number of residents and tourists.

The attitudes analysis has shown high level of the negative impacts of tourism in seven Adriatic counties, while in continental parts of Croatia tourism is seen as an activity with mostly positive effects. Still tourism has generally positive impact on the destination and is seen as desirable activity, even in areas with relatively high tourism function index. Accordingly, to enhance the positive impacts it is essential to diminish extremely big differences in tourism development between too developed coastal areas and mainly neglected continental part of the country and to reduce seasonality of tourism, trough sustainable management and diversification of tourism offer in accordance with spatial disparities.
\end{abstract}

Key words: Croatia; impact; tourism; local population; pressure; tourism function index

\section{Introduction}

Tourism has played in history and may play in the future a positive role in society, although it can also bring negative socio-economic effects if managed poorly. Among the possible negative socio-economic effects certainly stands out weakening of the local identity under the influence of tourism and weekend visitors. Another possible threat is the consumption of the most valuable areas for tourism, thereby reducing the possibility of using it by domestic pop-

* Institute for Tourism, Vrhovec 5, 10000 Zagreb, Croatia; Corresponding author: izidora.markovic@iztzg.hr 
ulation. Space in general and space used for tourism has to be perceived as a resource that has a geographic, social, economic, cultural, ecological and other value. From geographical point of view and for the purposes of regional planning it is necessary to develop adequate methods of evaluation of space in relation to tourism, which would take into consideration the physicalgeographic as well as socio-demographic characteristics of the area. Concern about the space and the population should not be at the responsibility of one sector, because space is the common good and whole community should benefit from it. Through activities in tourism culture and identity of specific destinations can be presented and preserved, but rapid growth of tourism can also cause negative impacts for the local population.

\section{Relation of tourism, space and population}

Every form of tourism is dependent on spatial resources and therefore the quality of space has crucial role in tourism development. For the purposes of tourism space should be beautiful and attractive, whether is it natural or artificially changed and therefore it is not unusual that tourism always tries to use the most valuable areas. Space for the purposes of tourism is therefore used on site and cannot be delivered as a raw material in another location (Marinović - Uzelac, 2001). Inexistence of planning or poor quality of planning activities in tourism, can damage or destroy the value of space. Inappropriate activities in the environment, especially those related to construction, can disrupt the landscape and diminish the spiritual value of space essential for the life of people in particular area (Butula, 2003). Especially dangerous are various forms of mass tourism construction in different spatial and temporal concentrations, because they can have very harmful and destructive influence on the natural, working and living environment of specified receptive region (Butler, Boyd, 200o). In this sense, tourism can be a "friend" or more often an "enemy" of the environment. Besides direct negative effects of tourism on space, the destruction of attractive environment can destroy tourism itself.

Because numerous activities in the tourism industry are causing pressure on the environment, new approaches are being explored in order to resolve conflict situations. Such approaches are generally viewed as the concept of sustainable development, because its main principle is based on keeping the quality of the environment future generations. Therefore tourism cannot be viewed without the components of space and environment (Kušen, 2001). But the environment as a resource for tourism activities irreversibly is changing by the development of tourism leaving traces on the ecological, sociological and cultural aspects (Klarić, Gatti, 2006). Therefore, we can say that tourism and the environment are in constant feedback, which by its characteristics in the initial and less intense stages is positive, but with the increase in tourist activity leads to occurrence of negative feedback (Carić, Marković, 2010).

Different views regarding the influence of tourism on the environment resulted also in different concepts regarding influence of tourism on the population. Due to the interests of the investors the pressure of tourism is often taken into account only on the micro-region or destination, but not in a wider area such as counties or the entire state where it is impossible to determine the long-term impact of tourism on the population (King et al, 1993). There is large and growing importance of the tourism in the economic welfare of the world, but equally significant is the extent to which tourism makes impact on the quality of life enjoyed by the citizens of the countries that are the source of tourists as well as those who host the tourists (Crouch, Ritchie, 1999). Development plans often neglect social aspects of tourism, such as 
necessity to provide sufficient number of educated labour force or population consensus about the direction of future development (Mayaka, Akama, 2007).

When the space for tourism is viewed primarily through economic value, it is not unusual that certain stakeholders are planning to sell or resell certain land (space), solely for the sake of earning a profit, while neglecting the needs of the community (Kranjčević, 2010). In other words, the degree of development of a particular administrative area is often measured only by economic parameters, while ignoring other parameters of sustainability (Harding, 2006). Therefore it is not unusual that such one-sided understanding of space can cause long-term negative consequences. The approach based on ignoring the fact that all areas are not equal with regard to their social aspects often leads to overdevelopment of some environmentally attractive areas, but sensitive from the socio-cultural aspect. Looking at the space in this way, we can ask whether it makes sense only investing in economically stronger areas, which would mean investing in a stronger economic space in order to "strengthen the fittest" (Thierstein, Förster, 2008).

Purely economic perception of space has resulted in the misconception of ownership over the space, as well as the role of tourism, whose activities should be directed to the preservation of the physical environment, but also welfare of indigenous communities (Swarbrook, 1999). Community is imposed by individual interests that are often presented as common, ignoring the real interests of the community. To make tourism development sustainable it is necessary to respect the socio-cultural authenticity of local communities, which is impossible without the strength to change reflections about the values of the area. Fortunately, more and more integrative framework exists for managing all facets of tourism development- relevance is to assess the extent to which tourism contributes (Croutch, Ritchie, 1999).

Tourism as a means of communication of different cultures is often seen as a means of bonding, but in recent years also as the reason for creating a conflict between the local community and tourists (Robinson, 1999; Macloed, 2006; Rekom, Go, 2006; Gu, Ryan, 2007). A large number of papers is dedicated to the impact of tourism on traditional socio-cultural and geographical identity, while often argues the change of identity under the influence of tourism, through weakening, but also potentially boosting the predominance of traditional identity (Vidal Gonzales, 2008; Gu, Ryan, 2006). Therefore the existing sustainability of space as well as a tool responsible for increase in its value, tourism is to the greatest extent responsible for the development of the entire community, because it governs and determines the limits of its growth (Saarinen, 2006). One of the goals of social sustainability is reduction of vulnerability and health maintenance of social and cultural systems (Sofield, 2003, Petrić, 2007), which in combination with sustainable development of tourism should strengthen the community. Individual scientific analysis of the relation between tourism and population suggest that tourism causes significant transformation of social sustainability, with the intensity that becomes increasingly prominent (Peračković, 2011).

The impacts of tourism on communities have attracted many studies (Butler, Hinch, 2007; Ryan, Aicken, 2005) and there is also a substantial literature regarding methods for measuring socio-cultural impacts (Archer et al., 2005), which are usually measured trough quantification of residents' perception of impact in Likert scale (Deery et al., 2005). A number of indicator-based frameworks have been proposed to conceptualize, predict and manage visitor impact on the environment and population. (Strickland-Munro et al., 2009; Torres - Delgado, Saarinen, 2014). These frameworks focus on the current state and have a substantial lack of change trough time and by its nature they disaggregate space on units that cannot be discussed separately from the surrounding area. 
Until now numerous typologies of Croatia have been done with regard to the level of tourism development through tourism regions. However there is a lack of the typology of municipalities with regard to the burden of local population with tourism. Thus, the entire coastal region of Croatia is characterized as predominantly strongly influenced by tourism according to its settlement characteristics (Lukić, 2012). Indicators of natural population growth of those settlements are on average more positive than all the others, except for dynamic, structurally stronger areas. But at the same time it is unknown to what extent their determination as primarily oriented to the development of tourism makes the pressure on the local population. Establishing this is one of the goals of this work, along with determination of the attitudes of the local population about tourism development in accordance with tourism pressure.

\section{Local community and tourism development}

Considering the sustainability of tourism, it is important to note that there is a number of indicators and models (Ko, 2005) with the aim of monitoring the individual components of sustainability. Very frequent are the issues of governance and development models of sustainable socio cultural development (Choi, Sirakaya, 2006), with the main aim of reducing social conflicts as a result of the unlimited growth of tourism (Yang et al., 2013). It is important to development planning models, which would at least partially anticipate and mitigate negative socio-cultural impacts on local communities (Strickland et al., 2010).

Tourism development is a double-edged sword for local communities directly affecting the current and future tourism industry development (Hanafiah et al., 2013). Positive attitudes in the community can encourage tourists' satisfaction levels and contribute to the word-ofmouth promotion among them. Therefore, the involvement and the participation of the host community are pertinent towards the success of the tourism development plan (Hanafiah et al., 2013). Continuous growth of number of tourist arrivals in certain time period can bring various changes in the destination. One of the reasons why these changes have to be monitored is that they may have negative impact on the destinations social, cultural and economic stability. To enhance the management of tourism in accordance with wishes and possibilities of local population it is of at most importance to gather information's of attitudes of local community concerning development of tourism (Andriotis, Vaughan, 2003;Ishikawa, Fukushibe, 2006; Zhang et al., 2006; Lepp, 2007).

Research conducted in this field is considered important because understanding the reasons why the residents do or do not support the tourism industry and its growth will help to establish models for such developments that minimize the negative social impacts and maximize the support for these initiatives (Varhgas- Sáchez et al., 2011). While residents may oppose to one type of development, they may be more willing to support another type. Thus a continuing assessment of locals' attitudes for different types of development may be necessary to assure sustainability of industry and to manage more critical aspects that appear as a tourism destination continues to develop (Gursoy, Dyer, 2009). It is very important to maintain level of tourist activity in the destinations in a healthy state, which will keep hospitable and friendly attitudes of locals to tourism and contribute to overall tourist satisfaction (Tomljenović, et al., 2013). 


\section{Methodology}

In this research data is based on two population censuses, from 2001 and 2011. This time frame was established as such because the previous censuses were conducted on administrative unites that are not comparable to unites existing today. Also because of the homeland war in ninety's in Croatia there has been big decline of population in some areas that cannot be discussed in terms of influence of tourism development and therefore it is neglected in this research. Data used from the census are total population on the level of municipality and number of tourism beds in municipality based on data from Business intelligence System in Tourism provided by Institute for Tourism.

In monitoring of the impact of tourism on the population, and also for the assessment of socio-cultural sustainability, as a indicator of tourism intensity of spatial pressure, coefficient of tourism functionality was used i. e. the Defert tourism activicty indicator (TAI), since it comprehensively shows the influence of various aspects of tourism on the community. This method of comparing the tourism nad second home related soatial pressure was taken from works of Kušen (1987), Klarić (1990), Avdimiotis et al. (2006), Blancasa, et al. (2011) and Opačić et al. (2009) in wich the autor determinated the level of turistification of Croatian coastal counties and analysed to what extant the second home dwellings and their owners enhanced the load intensisty of the Croatian coastal region. Also known as Tf index, this methods shows the relationship between the maximum number of tourists in the peak of the season in certain region and the number of permanent residents, expressed through the number of beds per 100 inhabitants. Although there are some other indicators, such as the ratio of the number of visitors / tourists or overnight stays by population, given the greater reliability of Tf index and its lower susceptibility to time changes, other indicators will not be considered here.

On the other hand, to determine social sustainability date used are from research of attitudes of the local population about the development of tourism, which was done for the purpose of drafting the Strategy of Croatian Tourism by 2020 (Institute for Tourism, 2013). The ascertain resident's attitudes to tourism development was conducted via telephone interview on a representative sample of 1.531 residents of the following regions: continental Croatia, inland of the Adriatic coast, the coastal belt and islands. The survey was carried out in September 2012, while the landline telephone directory was used as a sample frame. The households were randomly selected while the "birthday key" was used to randomly choose the respondent. Close-ended questions were used for statements relating to the tourism impact on community. The five point liker type scale was used with the appropriate steps taken to avoid the response set. Chi-square test was used to test the difference in distribution of answers between residents benefitting and those without any benefits from tourism. Given that the primary purpose of the data was the development of national tourism strategy there are no disintegrated data for the level of municipalities.

\section{Distribution of tourism function index in Croatia}

Analysis of the distribution of tourist function index in relation to the territorial division leads to the conclusion that the most important process of tourism transformation has affected the narrow coastal belt. Several areas that with strong tourist development can be extracted, especially Istria on the northernmost part of the Croatian Adriatic coast, but also Kvarner and middle Dalmatia region. Considering a situation on the county level as a special case compared to 
the other parts of Croatian coast, Istria County stands out with exceptionally high concentration of tourists compared to the local population (Tf index 110 in 2011 ), with all the municipalities in the period of the analysis recording further Tf index growth. In 2011 five coastal counties shows the value of $\mathrm{Tf}$ index between 60 and 49 (Zadar county 60, Primorje-Gorski Kotar county 58, Lika-Senj county 57, Šibenik-Knin county 54 and Dubrovnik-Neretva county 49), and just slightly lower index in the Split-Dalmatia County (33). This is considerably more than any of the continental counties, where Tf index is nowhere greater than 5 . The highest index is in Karlovac County (4. 4) due to the fact that it includes most of accommodation capacities of Plitvice Lakes National Park.

If we take into consideration more narrow area of cities and municipalities, areas of western Istria and the Makarska Riviera and parts of northern Adriatic islands of Cres, Krk, Rab and Pag with extremely high values of Tf index can be emphasized. In 2011 by far the highest Tf index are reported in municipalities Funtana (1737), Poreč (Tar-Vabriga (912) and Vrsar (863) in Istria, and greater than 500 in the municipalities of Lopar on the island of Rab (705), Baška on the island of Krk (675) and Podgora on Makarska Riviera (Table 1). Tf index greater than 300 are reported in the municipalities of Medulin and Brtonigla in Istria, in the remaining part of the Makarska Riviera, the entire area of the islands of Cres, Losinj, Krk, Rab, Pag, Vir, as well as in the municipality of Nin. As areas with a high concentration of tourists compared to the local population are emphasize the significant parts of the coastal area of Zadar and Šibenik-Knin County, except the cities of Zadar and Šibenik. These towns have significantly lower tourist function index because of their big demographic basis, which can easier neutralize the impact of big number of tourist beds on social sustainability.

Table 1. Top ten municipalities by tourism activity in 2001 and 2011

\begin{tabular}{|r|l|l|r|r|l|l|r|}
\hline & Municipality & Region & TF Index 2001 & & Municipality & Region & TF index 2011 \\
\hline 1. & Tar- Vabriga & North Adriatic/Coast & 986,1 & 1. & Funtana & North Adriatic/Coast & $1.737,0$ \\
\hline 2. & Lopar & North Adriatic/Island & 527,9 & 2. & Mali Lošinj & North Adriatic/Island & $1.687,6$ \\
\hline 3. & Vrsar & North Adriatic/Coast & 516,7 & 3. & Tar- Vabriga & North Adriatic/Coast & 912,1 \\
\hline 4. & Funtana & North Adriatic/Coast & 502,1 & 4. & Lopar & North Adriatic/Island & 705,0 \\
\hline 5. & Baška & North Adriatic/Island & 391,1 & 5. & Baška & North Adriatic/Island & 674,8 \\
\hline 6. & Nin & South Adriatic/Coast & 323,3 & 6. & Podgora & South Adriatic/Coast & 527,5 \\
\hline 7. & Punat & North Adriatic/Island & 318,7 & 7. & Baškavoda & South Adriatic/Coast & 482,3 \\
\hline 8. & Podgora & South Adriatic/Coast & 283,9 & 8. & Brela & South Adriatic/Coast & 466,8 \\
\hline 9. & Medulin & North Adriatic/Coast & 279,4 & 9. & Medulin & North Adriatic/Coast & 466,3 \\
\hline 10. & Tučepi & South Adriatic/Coast & 246,85 & 10. & Novalja & North Adriatic/Island & 431,5 \\
\hline
\end{tabular}

Source: BIST - Business Intelligence System for tourism, Institute for tourism Zagreb WebSite

When considering $\mathrm{Tf}$ index we also need to take account of location of certain municipalities, because excessive number of vulnerability of non-native residents almost always is higher on the islands then in the immediate vicinity of major urban centres. The Tf index is due to the large number of permanent residents lower in municipalities and cities with bigger demographic basis, even if the number of accommodation units is extremely large. Thus Tf index in Poreč (126. 2), Rovinj (241. 6), Crikvenica (196. 8) and in Dubrovnik (45. 4) are telling us that those are areas with moderate pressure of tourism activity, even though those are towns with big number of tourist beds. On the other hand, Tf index is particularly high in Municipality of Tar and Funtana, but due to the proximity of the town of Poreč has less 
weight then a lower Tf index in Lopar municipality on Rab or Baška on Krk Island, which are isolated settlements.

At the same time, while considering the relationship between the tourist function index in 2011 and in 2001, it is clear that in most coastal municipality it have increased significantly, primarily due to an increase in the number of beds in private accommodation, while in some destinations there has been lost in number of inhabitants. From the data (Figure 1) it is clear that relative values of Tf index have grown twice in one decade, which is the best indicator of mass construction of new accommodation facilities in the area of coast line and islands. Furthermore, number of island municipalities have raised from 3 to 4 , among first ten, and from 7 to 10 among first twenty municipalities by Tf index. That is concerning especially because of the pressure on the very sensitive natural environment, but also because of the pressure of tourism global identity on very fragile and traditional identity of the islanders. Also it is obvious from the data that North Adriatic region is having far bigger pressure on sustainability, both in 2001 and 2011, 7 of 10 municipialities with the highest Tf index are from North Adriatic region, while only three are from the South Adriatic Region.

On the other hand, in the continental area there has been increase in the tourism activity, but the values of the Tf index are still relatively low in most municipalities (Figure 2). The biggest increase has been detected in the area of the Rakovica municipality, from 68, 2 to 158, 7 (in both years it is the highest value of TF index on continent), which is due to its position near the UNESCO site, National park Plitvice lakes. Among other municipalities higher values have been detected in smaller municipalities with spa, such as Sv. Martin na Muri, Stubičke toplice and Varaždinske toplice in Northern Croatia. Zagreb as the most important continental tourist destination has relatively low index of tourism functionality, only 1, 06 in 2001 and 1, 5 in 2011, even though it has absolutely biggest growth of number of tourism beds from 8. 260 to 12 . 221 in 2011, because due to the big number of the inhabitants there is no significant pressure on the social sustainability in the city. Other areas with relative growth of Tf index are island of Korčula, Brač, Hvar and Krk, Pelješac peninsula, interior of Istria, north part of Međimurje county, part of Lika near NP Plitvice, all due to increase in number of beds. On the other hand, area around Velebit mountain in Kvarner region also had a significant increase of Tf index but it was due to loss of population.

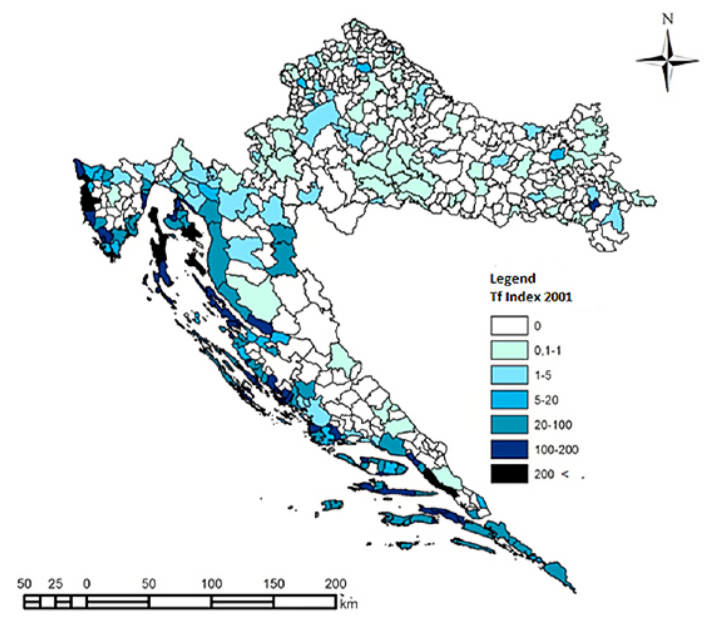

Figure 1. Towns and municipalities in Croatia 2001, due to the number of tourist beds per 100 residents

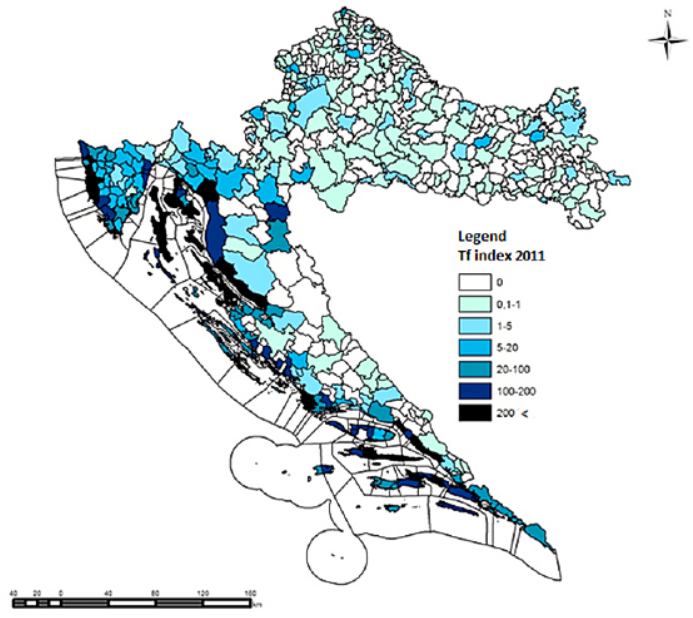

Figure 2. Towns and municipalities in Croatia 2011, due to the number of tourist beds per 100 residents 
To assess the endangerment of space and population with tourism type of capacity and seasonality of tourism is very important, since a greater proportion of higher quality primary accommodation capacities requested a greater number of labour force, while a pronounced seasonality implies a focus on seasonal workers and high pressures on infrastructure in the short summer period. An important factor is the origin of tourists and other people who live in the destination, especially the second home owners, since the disagreements between the local population and tourists decreased if the behavioural differences among them are smaller. Therefore, the sensitivity of the socio-cultural environment is regularly higher in rural areas and on islands than in big cities, and generally more urbanized areas. Other Mediterranean countries in a number of its regions have substantially higher tourist function indexes then Croatian regions with the highest concentration of tourism and the number of vacation homes owned by foreigners in many areas (eg Mallorca, Spain) significantly exceeds the number of the local population. Therefore, the current socio-cultural sustainability in Croatia can be assessed relatively favourable.

\section{Attitudes of local community}

The attitudes od local population were tested trough five point liker type scale, were (1) stands for highest impact and (5) for the lowest impact of tourism on certain apects of sustainability. Table 2 shows the medians for each impact on sustainability in touristic regions of Croatia. In general, residents have positive attitudes to tourism and the vast majority recognize tourism as a positive factor in development of their community. However, we can clearly notice that the issues of sustainability are far more critically viewed in more developed tourist regions on the coast. Tourism has the smallest negative impact on sustainability in the city of Zagreb and in the region of Continental Croatia, what is expected because of the low level of tourism activity that could not have strong impact on the most municipalities in Continental Croatia (Table 2). Thus, for 5 of 6 statements, over 50\% of residents of Zagreb and Continental Croatia said that tourism did not have negative influence at all.

Table 2. Negative impacts of tourism on destination sustainability

\begin{tabular}{|c|c|c|c|c|c|}
\hline \multirow[b]{2}{*}{ Statements } & \multirow[b]{2}{*}{ Total } & \multicolumn{4}{|c|}{ Region } \\
\hline & & $\begin{array}{c}\text { North } \\
\text { Adriatic }\end{array}$ & $\begin{array}{l}\text { South } \\
\text { Adriatic }\end{array}$ & $\begin{array}{c}\text { Continental } \\
\text { Croatia* }\end{array}$ & $\begin{array}{l}\text { City of } \\
\text { Zagreb }\end{array}$ \\
\hline Tourism has increased cost of living. & 2,5 & 3,1 & 3,0 & 2,1 & 2,2 \\
\hline $\begin{array}{l}\text { Further tourism development will undermine } \\
\text { quality of life in this town. }\end{array}$ & 1,9 & 2,2 & 2,1 & 1,8 & 1,7 \\
\hline $\begin{array}{l}\text { Tourist development has changed the appearance } \\
\text { of this town for worse. }\end{array}$ & 2,2 & 2,5 & 2,4 & 2,0 & 1,8 \\
\hline Tourists disturb public peace and public order. & 2,0 & 2,4 & 2,1 & 1,9 & 1,9 \\
\hline Tourists only create crowds and ques. & 2,0 & 2,3 & 2,4 & 1,7 & 1,7 \\
\hline Tourists are not spending enough. & 3,1 & 3,2 & 3,0 & 3,1 & 2,9 \\
\hline
\end{tabular}

*Without the city of Zagreb; Source: adopted by Institute for Tourism, 2013.

Only for the statement that concerned increased cost of living $20 \%$ of residents somewhat agreed, whilst all other statements they did not agree at all. The same we can say about positive effect of tourism development, because of the low level of the tourism activity there are very 
few positive effects on sustainability of community (Table 3). Only two positive effects that most of the respondents from the city of Zagreb recognized were higher tolerance to the tourists. In Continental Croatia there are also few positive impacts from tourism. In this region tourism had the smallest impact on increasing cultural and entertainment opportunities and on ensuring the survival of community ( $60 \%$ of residents do not agree with this statement).

Table 3. Positive impacts of tourism on destination sustainability

\begin{tabular}{|c|c|c|c|c|c|}
\hline \multirow[b]{2}{*}{ Statements } & \multirow[b]{2}{*}{ Total } & \multicolumn{4}{|c|}{ Region } \\
\hline & & $\begin{array}{l}\text { North } \\
\text { Adriatic }\end{array}$ & $\begin{array}{l}\text { South } \\
\text { Adriatic }\end{array}$ & $\begin{array}{c}\text { Continental } \\
\text { Croatia* }\end{array}$ & $\begin{array}{l}\text { City of } \\
\text { Zagreb }\end{array}$ \\
\hline $\begin{array}{l}\text { Because of the tourism my town has become a } \\
\text { better place to live. }\end{array}$ & 3,3 & 3,5 & 3,6 & 3,2 & 3,0 \\
\hline $\begin{array}{l}\text { Tourism has increased cultural and entertainment } \\
\text { opportunities. }\end{array}$ & 3,5 & 3,5 & 3,8 & 3,2 & 3,3 \\
\hline My place is special and should be protected. & 3,8 & 3,9 & 4,0 & 3,9 & 3,5 \\
\hline $\begin{array}{l}\text { Only tourism is able to ensure survival of the } \\
\text { community. }\end{array}$ & 2,5 & 3,0 & 3,0 & 2,2 & 1,8 \\
\hline $\begin{array}{l}\text { I would not mind presence of tourists' trough } \\
\text { whole year. }\end{array}$ & 4,3 & 4,1 & 4,3 & 4,2 & 4,5 \\
\hline I have nothing against tourists who spend less. & 3,8 & 3,6 & 3,7 & 3,7 & 4,0 \\
\hline
\end{tabular}

*Without the city of Zagreb; Source: adopted by Institute for Tourism, 2013.

Even though, deviations among the regions are not significant, negative impacts of tourism are most obvious in North Adriatic, where for 5 of 6 statements have the highest result (Table 3). As the most negative impact residents have identified increased costs of living (more than $40 \%$ agree or strongly agree with this statement). At the same time, in the North Adriatic region residents are the least concerned that further tourism development will undermine quality of life in this town ( $63 \%$ do not agree with this statement). On the other hand when it comes to positive effects of tourism on community, most of residents think that they are far higher than negative effect and among all regions they gave the biggest importance to the tourism for the survival of community (Table 4). Even though residents mostly agree with presence of tourists through whole year and they don't have nothing against tourists who spend less, they are relatively on the last place of all regions.

In the region of South Adriatic the majority of answers has shown positive opinion about the impacts of tourism on community, wherein they identified increased cost of living as the biggest threat to sustainability of community (Table 3). As positive impacts they recognized four of six statements with the highest rank among the regions, tourism made town a better place for life, tourism has increased cultural and entertainment opportunities, uniqueness of the place and importance of tourism as a positive factor for the economy of the local community. This kind of attitudes is expected since South Adriatic region is on the lower level of tourism development then the Northern Adriatic. 


\section{Conclusions and recommendations}

The main findings from the analysis can be summarized into two, at the first look, contradictory conclusions:

1. Tourism has generally positive impact on the destination and can be seen as desirable activity, especially in the actual circumstances when tourism is one of the rare economic activities in Croatia showing positive trends and creating new jobs; and

2. General attitudes of the population in Croatia regarding tourism are more positive in the areas where tourism is less developed and more negative in the areas where tourism represent the dominant economic activity.

If we analyse the situation from the spatial point of view, it is obvious that tourism is generally seen as positive phenomena in the continental part of Croatia including the city of Zagreb, where the majority of population does not see important negative impacts of tourism in their community. That is especially a case with the negative impacts of tourism regarding increase of the living costs and disturbances of public peace. In the continental part of Croatia the only negative impact that is viewed in the same way as in the coastal area is the opinion that tourists are not spending enough, what is caused with a fact that the prices are much lower than in the coastal areas.

Another reason for generally better attitudes of tourism in the continental part of Croatia is a fact that basic positive effects visible in the coastal areas cannot be recorded in the continent, because tourism is often not developed at all. That is especially visible through the statement that only tourism is able to ensure the survival of local community, which is common for the coastal areas where tourism is the most important activity. Therefore it is important to mention that BDP per capita, communal infrastructure and living standard in general are in Croatia much better in all seven coastal counties than in the thirteen continental counties, with only exception being the city of Zagreb due to its importance as the capital and the only bigger city in Croatia.

The main reason for some negative opinions about tourism in the coastal areas of Croatia is a fact that negative impacts are becoming more visible when tourism development becomes too intense and tourism is becoming the only important activity. Another factor causing less favourable opinions about tourism in the coastal areas is tourism seasonality, with a consequence in very low permanent job offer in most developed tourism areas functioning often less than four months during the year.

There are slight differences between more developed Northern Adriatic and less developed South Adriatic, showing more critical attitudes in the North, are additionally proving the conclusion that tourism is seen as a threat when its volume becomes too large according to the opinion of the local community. The only attitude not fitting in this scheme is a statement that tourism only creates crowds and queues, which is seen as negativeimpact in the Southern Adriatic. Such attitude can be explained with the generally lower quality of tourism and less efficient organization in less developed South, oriented more to tourists from the Central and Eastern Europe, while the Northern Adriatic is oriented mainly on the Western European market.

As a general conclusion, we can say that two at the first look contradictory conclusions are in fact not in contradiction. Tourism in Croatia is definitely an activity that has mainly positive impacts on the society due to its importance for the overall economy and the improvement on life quality, but it can become a negative phenomenon if its development is becoming too 
strong and is starting to create negative impacts on the natural and social environment. That is especially case in the areas where tourism is representing almost the only economic activity and where tourism is producing huge pressure on the local infrastructure during the short summer season and on small communities distant to bigger functional centers (towns with more then 10. ooo citizens).

There is a great need and numerous possibilities for diversification of tourism offer in Croatia trough spatial redistribution of tourists' facilities and products. Current situation is an outcome of continuous spontaneous development which has not been managed by the state. Also this is causing decrease of the wellbeing of the community, along with the concerning demographic extension. Therefore it can be concluded that in a case of Croatia it is necessary to diminish actuall extreme big differences in tourism development between too developed coastal areas and mainly neglected continental part of the country. Besides the necessity of consciousness regarding growth of tourism, it is also important to reduce seasonality of tourism as generally negative impact from the natural, socio-cultural and economic point of view. Therefore in the actual Strategy of Croatian tourism redistribution of tourism activities to the undeveloped continental areas and reduction of seasonality in the coast are crucial for the achievement of the desired sustainable development scenario.

\section{References}

Andriotis, K., Vaughan, D. R. 2003. Urban Residents' AttitudesTowards Tourism Development: TheCase of Crete. Journal of Travel Research 42(2), 172-185.

Archer, B. H., Cooper, C., Ruhanen, L. 2005. Thepositiveand negative impacts of tourism. In: Theobald W. F. (Ed. ) Global Tourism (pp. 79-103). Burlington: Elsevier.

BIST - Business Intelligence System for tourism, Institute for tourism Zagreb WebSite; at: http://bist. iztzg. hr/bist/login. asp

Blancasa, F. J., Lozano-Oyolaa, M., Gonzálezb, M., Guerreroa, F. M., Caballerob, R. 2011. How to use sustainability indicators for tourism planning: The case of rural tourism in Andalusia (Spain). Science of the Total Environment 412-413, 28-45.

Butler, R. W., Boyd, S. W. (eds. )20oo. Tourism and national parks: issues and implications. Wiley\&SonsLtd, Chichester, 342 pp.

Butler, R. W., Hinch, T. (eds. ) 2007. Tourism and Indigenous Peoples. Elsevier, Oxford, 40o pp.

Butula, S. (2003). Planning for Sustainable Development: the Significance of Different Social Interests in Landscape. Društvenja istraživanja 12 (3-4), 427-4.45.

Carić, H., Marković, I. 2010. Integralno planiranje u turizmu kao temelj održivog razvoja [Integratedtourismplanning as a basis of sustainable development]. In: Čorak, S. (Ed. ) Izazovi upravljanja turizmom (pp. 123-138). Institut za turizam, Zagreb. (in Croatian with English summary)

Choi, H. C., Sirakaya, E. 2006. Sustainability indicators for managing community tourism. Tourism Managment 27, 1274-1289.

Crouch, G. I., Rithie, J. R. B. 1999. Tourism, Competitiveness, and Societal Prosperity. Journal of Business research 44, 137-152.

Deery, M., Jago, L., Fredline, L. 2005. A framework for the development of social and socioeconomic indicators for sustainable tourism in communities. Tourism Review International 9(1), 69-77. 
Gu, H., Ryan, C. 2008. Place attachment, identity and community impacts of tourism the case of a Beijinghutong. Tourism Managment 29, 637-647.

Gursoy, D., Chi, C. G., Dyer, P. 2009. An Examination of Locals' Attitudes. Annals of Tourism Research 36, 723-726.

Hanafiah, M. H., Jamaluddin, M. R., Zulkifly, M. I. 2013. Local Community Attitude and Support towards Tourism Development in Tioman Island, Malaysia. Procedia - Social and Behavioral Sciences 105, 792-800.

Harding, R. 2006. Ecologically sustainable development: origins, implementation and challenges. Desalination 187. 229-239.

Ishikawa, N., Fukushibe, M. 2006. Who expects the municipalities to take initiative in tourism development? Residents' attitudes of AmamiOshima Island in Japan. Tourism Management $28,461-475$.

Institute for tourism (2013). Strategija razvoja turizma Republike Hrvatske do 2020. godine [Tourism Development Strategy of the Republic of Croatia until 202o]. Vlada Republike Hrvatske, Zagreb, 89 pp. (In Croatian)

King, B., Pizam, A., Milman, A. 1993. Social impacts of tourism: Host perceptions. Annals of Tourism Research 20, 650- 655.

Klarić, Z., Gatti, P. 2006. [Ekoturizam]. In: Čorak, S., Mikačić, V. (Eds. ), Hrvatski turizam plavo, bijelo, zeleno (pp. 149-166), Institut za turizam, Zagreb. (in Croatian with English summary)

Klarić, Z. 2013. The Pressure on the Coastal Area as a Factor of Sustainability. Academica Turistica 6, 61-70.

Ko, T. G. 2005. Development of a tourism sustainability assessment procedure: a conceptual approach. Tourism Management 26, 431-445

Kranjčević, J. 2010. Planiranje korištenja zemljišta - Usporedba načina i sustava planiranja u nekim državama članicama EU i Republike Hrvatske - prikaz knjige [Land use planning Comparison of methods and systems planning in some EU member states and the Croatia - book review]. Hrvatska pravna revija, Časopis za promicanje pravne teorije i prakse 10, 111-115. (in Croatian)

Kušen, E. 2001. Turistička atrakcijska osnova [Tourism attraction base]. Institut za turizam Zagreb, 262 pp. (in Croatian with English summary)

Lepp, A. 2007. Residents' attitudes towards tourism in Bigodi village, Uganda. Tourism Managment 28, 876-885.

Lukić, A. 2012. Mozaik izvan grada, tipologija ruralnih i urbaniziranih naselja Hrvatske [Mosaic outside th ecity, the typology of rural and urbanized settlements of Croatia]. Meridijani, Samobor, 256 pp. (in Croatian with English summary)

Macloed, D. V. L. 2006. Power, Resources andIdentity: The Influence of Tourism on Indigenous Communities. In: Burnes, P. M., Novelli, M. (Eds. ), Tourism and Social identities: Global Frameworks and Local Realities (pp 111-125). Elsevier, Amstradam.

Marinović-Uzelac, A. (2001). Prostorno planiranje [Spatial Planning]. Dom i svijet, Zagreb, 548 pp. (in Croatian with English summary)

Mayaka, M., Akama, J. S. 2007. Systems approach to tourism training and education: The Kenyan case study. Tourism management 28(1), 298-306.

Opačić, V. T., Mikačić, V. 2009. Second home phenomenon and tourism in the Croatian littoral - two pretenders for the same space. Tourism 57(2); 155-175

Pejnović, D., Marković, I., BoranićŽivoder, S. 2013: Influence of tourism development on sustainability of local communities in natural protected areas, case study of Plitvice lakes 
National park. In: International critical tourism studies conference Proceeding (Ed. Čaušević, S. ). Retrieved from http://cts. som. surrey. ac. uk/sample-page/tourism-and-its-potentialas-a-social-force/?wpa-paged $=2$

Peračković, K. 2011. Hrvatska u postindustrijsko doba-obilježja promjena u strukturi aktivnog stanovništva Hrvatske po sektorima djelatnosti i spolu [Croatia in the post industrial era-feature changes in the structure of the active population of Croatia by sectors of activity and sex]. Društvena istraživanja 20 (1), 89-110.

Petrić, L. 2007. Osposobljavanje lokalnih zajednica za održivi razvoj turizma [Empowerment of communities for sustainable tourism development]. Interdisciplinary Journal Tourism 55(4), 431-443. (in Croatian with English summary)

Rekom, R. V., Go, F. 2006. Cultural Identities in Globalizing World: Conditions for Sustainability of Intercultural Tourism. In: Burnes, P. M., Novelli, M. (Eds. ), Tourism and Social identities: Global Frameworks and Local Realities (pp. 79-91). Elsevier, Amstradam.

Ryan, C., Aicken, M. (eds. ) 2005. Indigenous Tourism: The commodification and Management of Culture. Elsevier, Amsterdam, 284 pp.

Robinson, M. 1999. Is Cultural Tourism on the Right Track?. UNESCO Courier 52 (7/8), 22.

Saarinen, J. 2006. Traditions of Sustainability in Tourism Studies. Annals of Tourism Research 33, 1121-1140.

Sofield H. B. T. (ed. ) 2003. Empowerment for Sustainable Tourism Development. Pergamon, Oxford, $410 \mathrm{pp}$.

Strickland, J. K., Allison, H. E., Moore, S. A. 2010. Using Resilience Concepts to Investigate the Impacts of Protected Area Tourism on Communities. Annals of Tourism Research 37 (2), 199-519.

Swarbrook, J. 1999. Sustainable tourism management. CABI Publishing, New York, 371 pp.

Thierstein, A, Förster, A. 2008. The Image and The Region - Making Mega-City Regions Visible!. Lars Müller Publishers, Baden, 203 pp.

Tomljenović, R., Boranić Živoder, S., Marušić, Z. 2013. Podrška interesnih skupina razvoju turizma [Support to development of tourism stakeholders]. Actaturistica, 25 (1), 73-102. (in Croatian with English summary)

Torres - Delgado, A., Saarinen, J. 2014. Using indicators to assess sustainable tourism development: a review. Tourism Geographies 16(1), 31-47.

Varhgas- Sáchez, Porras-Bueno, N., Plaza- Mejíha, M. A. 2011. Explaining Residents' Attitudes to Tourism. s a universal model possible?. Annals of Tourism Research 38(2), 460-480.

Vidal-Gonzáles, M. 2008. Intangible heritage tourism and identity. Tourism Managment 29, 807-810.

Yang, J., Ryan, C, Zgang, L. 2013. Social conflict in communities impacted by tourism. Tourism Management 35, 82-93.

Zhang, J., Inbakaran, R., Jackson, M. 2006. Understanding community attitudes towards tourism and host-guest interaction in the urban-rural border region. Tourism Geographies $88(2), 182-204$. 